\title{
COMPARATIVE ANALYSIS OF INSULIN-LIKE GROWTH FACTOR I AND TUMOUR-ASSOCIATED ANTIGENS IN CANCER PATIENTS AT THE TIME OF DIAGNOSIS
}

\author{
Ronalds Mačuks*, Ludmila Eṇǵele ${ }^{\star *}$, Inta Nuḳe**, Agnese Sudraba***, \\ and Simona Doniņa ${ }^{* * * * * *}$ \\ * Rīga Pauls Stradiṇš University, Dzirciema iela 16, Rīga, LV-1007, LATVIA, \\ e-mail: r.macuks@gmail.com \\ ** Latvian Oncology Centre, Rīga Eastern Clinical University Hospital, Hipokrāta iela 4, Rīga, LV-1079, LATVIA \\ *** Rīga Eastern Clinical University Hospital „Linezers”, Linezera 6, Rīga, LATVIA \\ ${ }^{* * \star *}$ August Kirchenstein Microbiology and Virusology Institute, Rīga Stradiṇš University, Rāsupītes iela 1, Rīga, LV-1067, LATVIA, \\ e-mail: donsimon@inbox.Iv
}

Communicated by Andrejs Ërglis

\begin{abstract}
Insulin-like growth factor-1 (IGF-1) is a polypeptide hormone with structure similar to insulin. Many experimental data support the suggestion that risk of cancer is higher among persons with raised concentration of IGF-1 and some studies support the role of IGF-1 as a biomarker of increased risk of development of colorectal (CRC) and breast cancer (BC). We have determined IGF-1, CA19-9, CEA, CA72-4 for colorectal, CA15-3 and CEA for breast cancer to clarify utility of IGF-1 as a biomarker of cancer presence at the time of diagnosis. In total, 42 men and 52 women with CRC and 139 women with BC were examined. The cut-off level for IGF-I concentration in serum was established from results of apparently healthy 27 men and 130 women. An IGF-I and tumour-associated antigens were detected by chemiluminescence's method using analyser Immulite 2000 (Siemens). Elevated level of IGF-1 was detected in $42.8 \%$ of men and $30.7 \%$ of women with colorectal cancer. The highest detection rates for CRC using a two biomarker combination were for men as well as for women (57.1\% and 57.6\%). IGF-1 showed higher detection rates between women with breast cancer in postmenopause vs. women at premenopausal age (33.6\% vs. 27.7\%). IGF-1 can be used as an additional biomarker for selected colorectal and breast cancer patient groups.
\end{abstract}

Key words: IGF-I, colorectal, breast, cancer.

\section{INTRODUCTION}

Breast (BC) and colorectal cancer (CRC) are solid tumours with high incidence in Latvia as well as in Europe. Despite of screening programmes started in 2009, early detection still is not sufficient. In the future it is likely that a combined approach simultaneously using multiple markers would be most successful in detection of early breast cancer in asymptomatic patients (Brooks, 2008).

Well-known tumour-associated antigens CA15-3, CEA, CA19-9, and CA72-4, which are used as serological tumour markers for breast and colorectal cancer and usually correlate with tumour bulk, do not have enough sensitivity at the time of diagnosis. Determination of growth factors in cancer patient serum may serve as an additional biomarker to improve tumour detection at an early stage.

The insulin-like growth factor system, which includes insulin-like growth factors (IGF-I and IGF-II), IGF receptors
(IGF-IR and IGF-IIR) and IGF binding proteins (IGFBPs), plays an important role in epithelial growth, anti-apoptosis, mitogenesis and angiogenesis (Durai et al., 2005).

Over the past three decades considerable evidence has accumulated indicating that IGF-I may play an important role in maintaining and supporting progression of cancer growth (Holly et al., 1999). The mitogenic and antiapoptotic effects of IGF-I suggest that the main tumourigenic effect of this growth factor is as a tumour promoter rather than carcinogenic initiator. Neoplastic cells are more likely to develop into carcinoma in the presence of high IGF-I levels (Jenkins et al., 2004). It is suggested also by several prospective studies that individuals with higher serum IGF-I levels within the normal range have an increased risk of the most common cancers, such as colon, breast, lung and prostate cancer (Hankinson et al., 1998).

The growth promoting effects of IGF-I and IGF-II on cancer cells are mediated through the IGF-IR, which is a tyro- 
sine kinase, and cancer cells with higher expression of the IGF-IR have a strong tendency to metastasise. Most of the IGFs in circulation are bound to the IGFBPs, which regulate the bioavailability of the IGFs. All IGFBPs inhibit IGF action by high affinity binding, while some of them also potentiate the effects of IGFs. Colon cancer cells produce specific proteases that degrade the IGFBP so that the IGF will be free to act on the cancer cell in an autocrine manner. Therefore, the IGFBPs may have a crucial role in the development of the colon cancer (Durai et al., 2005).

IGFs are involved in normal mammary gland development, but have also been implicated in the pathogenesis of breast cancer (Fürstenberger et al., 2003).

Circulating IGF-I was described as breast cancer risk biomarker and elevated level of this growth factor was documented during carcinogenesis and tumour formation before clinical verification of the disease (DeLellis et al., 2003).

The aim of the study was to determine circulating IGF-I levels in breast and colorectal cancer patients at the time of diagnosis prior to any treatment, simultaneously with the well known BC serological markers CA15-3 and CEA and CRC markers CEA, CA19-9, CA72-4, in order to clarify the utility of circulating IGF-I as an additional biomarker of BC and CRC.

\section{MATERIALS AND METHODS}

A total of 94 CRC and 139 BC patients with histologically confirmed adenocarcinomas were examined at stage I - II of the disease. The circulating level of IGF-I in serum was determined for cancer patients at the time of diagnosis and results were compared with circulating IGF-I in agematched healthy control group (27 men and 130 women) mean levels. Tumour-associated antigens CEA, CA19-9, Ca72-4 and CA15-3 were measured simultaneously. For accepted markers the cut-off levels of CEA $<5 \mathrm{ng} / \mathrm{ml}$, CA19-9 < $18 \mathrm{U} / \mathrm{ml}, \mathrm{CA} 72-4<6.9 \mathrm{U} / \mathrm{ml}$ and CA15-3 $<38$ $\mathrm{U} / \mathrm{ml}$ were used. As IGF-I cut-off level, mean IGF-I serum concentration found in healthy subjects was used. For interpretation of the IGF-I level in the control group, participants were divided according to gender and women also according to the menopausal status. In the same manner, the study group of CRC patients was divided into men and women subgroup and breast cancer patients - according to menopausal status (Table 1).

Tumour markers as well as IGF-I were detected in patient serum from the same sample by standard enzyme-labelled chemiluminescent immunometric assay using a Siemens analyser Immulite 2000 and commercial kits with corresponding antibodies (Anonymous, 2002).

The study was approved by the Ethics Committee of Latvian Institute of Experimental and Clinical Medicine.
CHARACTERISTICS OF PATIENTS AND CONTROL

\begin{tabular}{c|c|c|c|c|c}
\hline Groups & Cancer site & Gender & Age range & $\begin{array}{c}\text { Menopausal } \\
\text { status }\end{array}$ & $\mathrm{n}$ \\
\hline 1 & CRC & male & $45-76$ & - & 42 \\
2 & CRC & female & $38-74$ & na & 52 \\
3 & BC & female & $48-72$ & postmen & 113 \\
4 & BC & female & $34-53$ & premen & 36 \\
control 1 & - & male & $38-74$ & - & 27 \\
control 2 & - & female & $31-69$ & na & 130 \\
control 3 & - & female & $47-69$ & postmen & 82 \\
control 4 & - & female & $31-52$ & premen & 48
\end{tabular}

na, not available

\section{RESULTS}

The mean circulating level of IGF-I was $111.0 \pm 35.9 \mathrm{ng} / \mathrm{ml}$ in healthy men and $138.4 \pm 34.6 \mathrm{ng} / \mathrm{ml}$ in healthy women. The value of the growth factor in serum differed in pre- and postmenopausal women $(162.0 \pm 58.3$ and $122.0 \pm 38.7$ $\mathrm{ng} / \mathrm{ml}$, respectively). Mean concentration of IGF-I in CRC patients was $102.61 \pm 45.3 \mathrm{ng} / \mathrm{ml}$ for men and $115.47 \pm$ $59.63 \mathrm{ng} / \mathrm{ml}$ for women. No statistically significant difference of the mean concentration of IGF-I was observed between control group and CRC patients. The premenopausal and postmenopausal BC patient serum level of IGF-I was $144.1 \pm 44.5 \mathrm{ng} / \mathrm{ml}$ and $112.0 \pm 46.0 \mathrm{ng} / \mathrm{ml}$, respectively. The difference between $\mathrm{BC}$ patients and control group did not reach statistical significance (Fig. 1).

In the first group of men with CRC prior to any treatment, IGF-I was elevated in 18, CA19-9 in 12, CEA and CA72-4 in 9 patients of 42 .

When combining markers, the highest detection rate was achieved using a combination of CA19-9 and IGF-I. Further attachment of a third biomarker offered insignificant improvement in detection rate (Fig.2a).

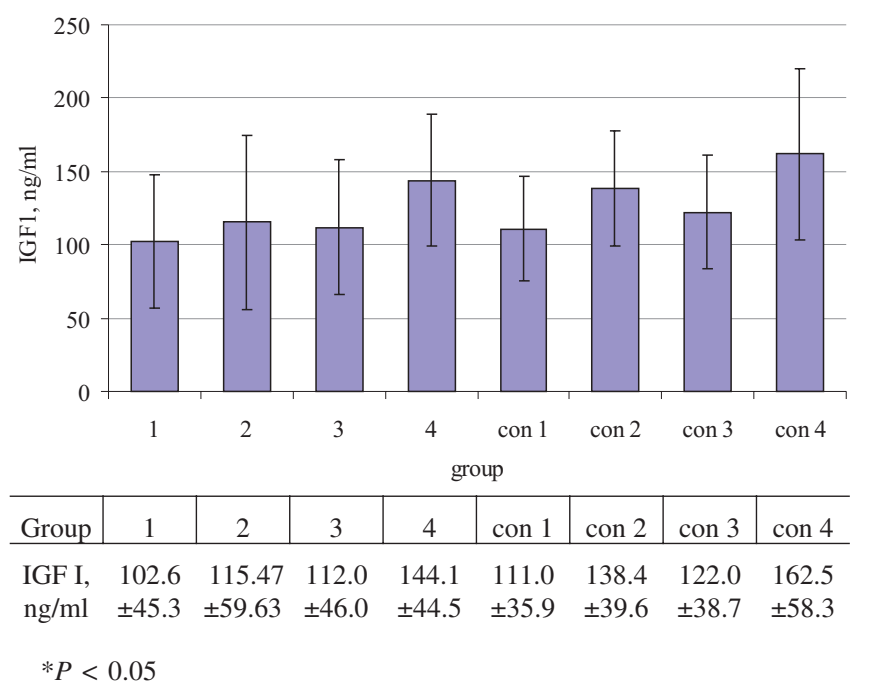

Fig. 1. Mean serum concentration of IGF I in patients and control. 


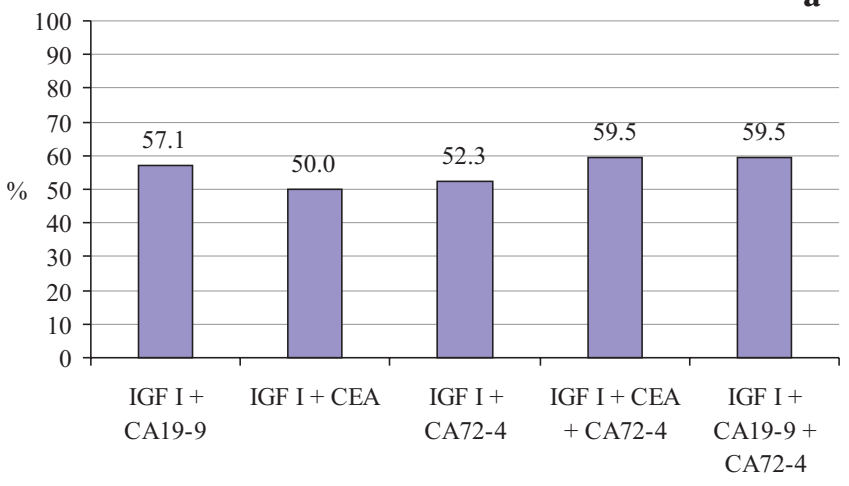

biomarkers

Group 1

b

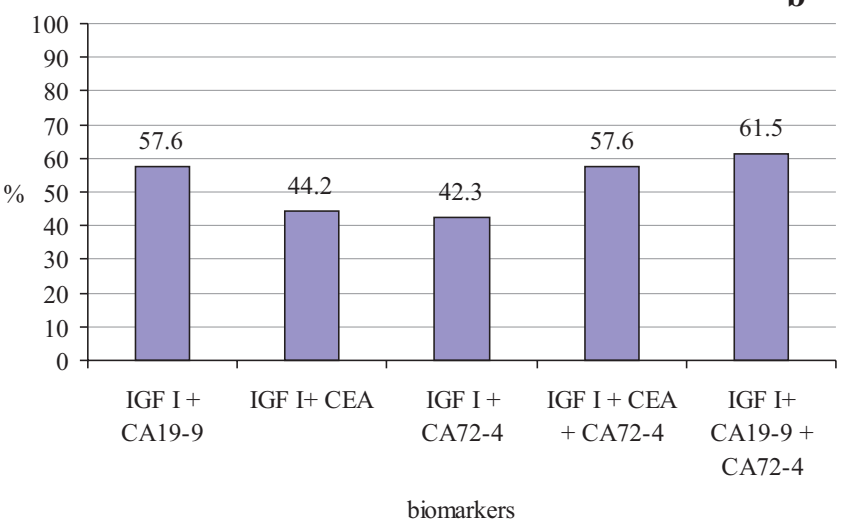

Group 2

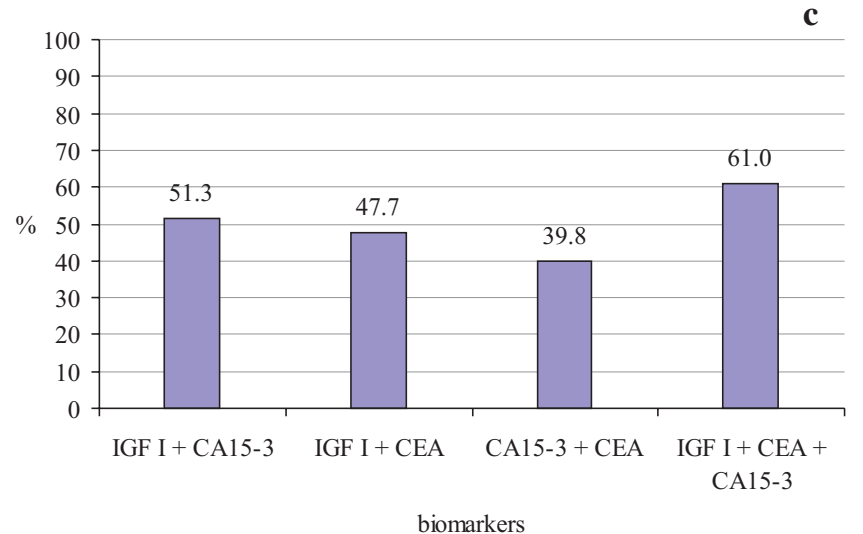

biomarkers

Group 3

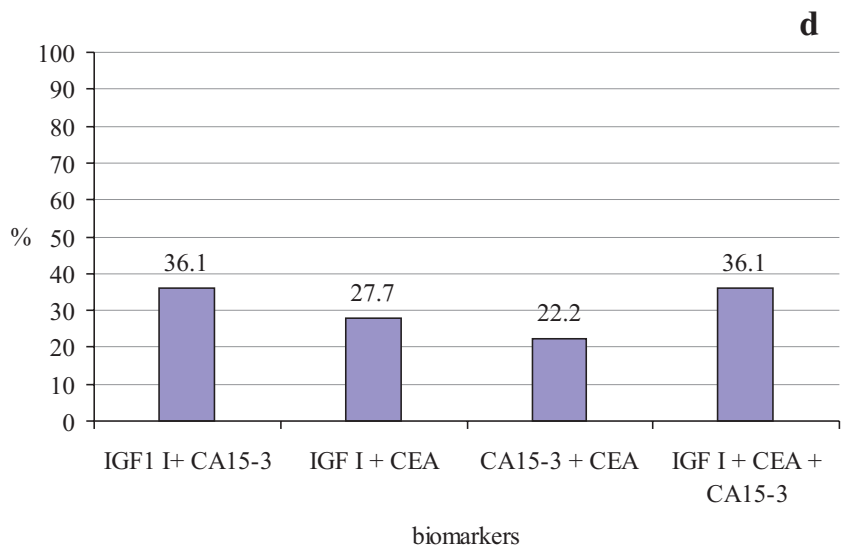

Group 4

Fig. 2. Biomarker combination detection rates

In bivariate correlation analysis, the Spearman's test showed a correlation between IGF-1 and CA19-9 (correlation coefficient $0.439 ; P<0.01$ ). Among women with CRC (group $2)$, IGF-I was elevated in $16(30.7 \%)$, CA $19-9$ in 12 (23.0\%), CEA in 10 (19.2\%) and CA72-4 in 19 (36.5\%) patients of a total of 52 patients before any treatment.

Biomarker concentrations in the second group showed superior detection rates using IGF-I and CA 19-9, adding also CA72-4, with 30 detected CRC and with 32 detected CRC patients from 52 cases (Fig. 2b)

Spearman's bivariate correlation analysis detected a statistical significance correlation between CA72-4 and CA19-9 (correlation coefficient $0.287 ; P<0.05$ ).

Comparing the detection rates of IGF-1 between the first and second study group, the difference was not significant, but the IGF-1 detection rates were higher among men, 18 from 42 vs. 16 of 52 (Chi-square, Yates corrected value $0.99 ; P=0.318)$. No significant difference was found also for the combination of CA19-9 and IGF-1: 24 of 42 vs. 30 of 52, respectively (Chi-square, Yates corrected value 0.02; $P=0.875)$.

In postmenopausal BC patients (group 3) IGF-I was elevated above the cut-off level in $33.6 \%$, CEA in $19.4 \%$ and
CA15-3 in $28.3 \%$. When IGF-I was combined with CA15-3 detection rates increased by an additional 20 detected breast cancer cases and addition of CEA improved detection rates up to 69 of 113 patients (Fig. 2c). However, no significant correlations were found in the group of postmenopausal BC patients.

Premenopausal BC patients (group 4) IGF-I showed the highest detection rate of the three biomarkers: elevated in 10 of $36(27.7 \%)$ BC patients. A CEA value above the cut-off level was detected in $3(8.3 \%)$ and CA15-3 in 7 (19.4\%) cases in this group.

The highest detection rates for combination of biomarkers were shown by IGF-I in combination with CA15-3. Addition of a third marker did not improve the $\mathrm{BC}$ detection rate (Fig. 2d).

In the premenopausal age group there was an observed significant correlation between IGF-1 and CEA (Pearson's correlation 0.564, $P<0.001$ ), IGF-1 and CA15-3 (Pearson's correlation 0.552, $P<0.001)$. Comparing marker levels in menopause and premenopause, a significant correlation was shown only for IGF-1 (Pearson's correlation 0.919, $P<$ 0.001). 


\section{DISCUSSION}

A review of various studies concludes that the well known serological tumour marker CEA as well as CA19-9, CA72-4 for CRC and CA15-3 for BC alone are with negligible diagnostic value for detection of cancer lesions especially at the early stages (Delarue et al., 1988; Duffey, 2001; Chen et al., 2005; Tan et al., 2009).

Schiemann et al. (2005) reported that $34 \%$ of patients with sporadic CRC showed elevated CEA levels higher than 5 $\mathrm{ng} / \mathrm{ml}$ at the time of diagnosis for all stages. Our data showed that in only $21.4 \%$ of men with CRC and in $19.2 \%$ of women with CRC a CEA value was found above the cut-off level, which confirms insufficient sensitivity of the mentioned markers for early detection.

Similar observations have been made for the carbohydrate antigen CA19-9, which showed lack of sensitivity as diagnostic marker for CRC (Carpelan-Holmström et al., 2002; Chen et al., 2005). Our data support this suggestion. Tumour-associated antigen CA72-4 estimated in our study for CRC patients was used as gastric and mucinous ovarian cancer marker. In patients with CRC, an elevated level of CA72-4 from $25 \%$ to $36 \%$ was observed (Carpelan-Holmström et al., 2002). No other studies have suggested an elevated level of CA72-4 in CRC according to gender. The most observed elevated level of CA72-4 in women with CRC in our study may be explained by the effect of steroids on metabolism of tumour-associated antigen.

The results regarding cancer detection in both $\mathrm{BC}$ patient groups were less informative when traditional serum markers were determined. This is supported by some studies of serum tumour markers in premenopausal women for diagnostic purposes. During the last two decades, with the same aim to improve diagnostic sensitivity for cancer detection various tumour marker panels have been designed. A combination of two to four different serum markers reflecting the tumour mass have shown some advantage (Delarue et al., 1988; Fernandes et al., 2005).

Additional detection of growth factors seems to be promising (Dbouk et al., 2007). Circulating concentration of IGF-I, which might be associated with an increased risk of cancer including $\mathrm{BC}$ and $\mathrm{CRC}$, was measured as cancer risk biomarker (Johansson et al., 2004; Renehan et al., 2004; Morimoto, 2005) and some studies report significantly higher levels of IGF-I in blood of CRC patients compared to the controls (Kaczka et al., 2007; Tripkovic et al., 2007).

In our study, measurement of circulating IGF-I was performed only at the time of diagnosis and we have no information about IGF-I levels in patient serum before illness. However, when cancer was confirmed, $34 \%$ of postmenopausal BC women had elevated IGF-I levels in serum according to the accepted cut-off level. This might be influenced by circulating steroid levels, interaction between gonadotrophic hormones, IGFPs, and IGF-I in postmenopausal women. There is evidence that the most frequent ele- vation of IGF-I in men with CRC can be explained by host tumour interactions and biology of colorectal adenocarcinoma (Morimoto, 2005).

Elevated serum IGF-I levels in cancer patients may simply be a surrogate measure of some different processes in complicated interactions during carcinogenesis and cancer development and progression (Jenkins et al., 2004). IGF-I levels may be elevated in the absence of cancer, and in more cases than not of circulating IGF-I levels did not reflect presence of a malignant tumour, unfortunately like a majority of serological biomarkers.

Our data suggest that detection of the circulating IGF-I alone could not be recommended for detection of BC in preand postmenopausal women as well in men and women with CRC.

Improvement of the detection rate using combinations of growth factor IGF-I and markers of tumour bulk was observed in all examined groups especially in postmenopausal $\mathrm{BC}$ patients and men with CRC. This data indicates that the addition of markers reflecting cancer cell biology and host response to the tumour could be useful as additional biomarkers for understanding tumour biology, tumour - host interactions and individualisation of the biomarker panel for each patient.

\section{ACKNOWLEDGEMENTS}

The work was supported by the National Research Programme in Medicine 2006-2009, project No. 3, "Development of diagnostic methods for detection of cancer risk factors, early diagnostics of cancer and pre-cancer conditions, and optimisation of tumour treatment". Special thanks to Professor Uldis Teibe for statistical analyse advises and Laima Graudina for graph processing.

\section{REFERENCES}

Anonymous (2002). Revision I. Version 4 x Y, Diagnostic Products Corporation, USA.

Brooks, M. (2009). Breast cancer screening and biomarkers. Surg. Oncol., 18(1), 15-24.

Carpelan-Holmström, M., Louhimo, J., Stenman, U.H., Alfthan, H., Haglund, C. (2002). CEA, CA 19-9 and CA 72-4 improve the diagnostic accuracy in gastrointestinal cancers. Anticancer Res. 22(4), 2311-2316.

Chen, C.C., Yang, S.H., Lin, J.K., Lin, T.C., Chen, W.S., Jiang, J.K., Wang, H.S., Chang, S.C. (2005). Is it reasonable to add preoperative serum level of CEA and CA19-9 to staging for colorectal cancer? J. Surg. Res., 124(2), 169-74.

Dbouk, H.A., Tawil, A., Nasr, F., Kandakarjian, L., Abou-Merhi, R. (2007). Significance of CEA and VEGF as Diagnostic Markers of Colorectal Cancer in Lebanese Patients. Open Clin. Cancer J., 1, 1-5.

Delarue, J.C., Mouriesse, H., Dubois, F., Friedman, S., May-Levin, F. (1988). Markers in breast cancer: Does CEA add to the detection by CA 15.3? Breast Cancer Res. Treat., 11(3), 273-276.

DeLellis, K., Ingles, S., Kolonel, L., McKean-Cowdin, R., Henderson, B., Stanczyk, F., Probst-Hensch, N.M. (2003). IGF1 genotype, mean plasma level and breast cancer risk in the Hawaii/Los Angeles multiethnic cohort. Brit. J. Cancer, 88(2), 277-282. 
Durai, R., Yang, W., Gupta, S., Seifalian, A.M., Winslet, M.C. (2005). The role of the insulin-like growth factor system in colorectal cancer: Review of current knowledge. Int. J. Colorectal Dis., 20(3), 203-220.

Fernandes, L.C., Kim, S.B., Matos, D. (2005). Cytokeratins and carcinoembryonic antigen in diagnosis, staging and prognosis of colorectal adenocarcinoma. World J. Gastroenterol., 11(5), 645-648.

Fürstenberger, G., Morant, R., Senn, H.J. (2003). Insulin-like growth factors and breast cancer. Onkologie, 26(3), 290-294.

Hankinson, S.E., Willett, W.C., Colditz, G.A., Hunter, D.J., Michaud, D.S., Deroo, B., Rosner, B., Speizer, F.E., Pollak, M. (1998). Circulating concentrations of insulin-like growth factor-I and risk of breast cancer. Lancet, 351(9113), 1393-1396

Holly, J.M., Gunnell, D.J., Davey Smith, G. (1999). Growth hormone, IGF-I and cancer. Less intervention to avoid cancer? More intervention to prevent cancer? J. Endocrinol., 162(3), 321-330.

Jenkins, P.J., Bustin, S.A. (2004). Evidence for a link between IGF-I and cancer. Eur. J. Endocrinol., 151 (Suppl 1), S17-22.

Johansson, H., Baglietto, L., Guerrieri-Gonzaga, A., Bonanni, B., Mariette, F., Macis, D., Serrano, D., Sandri, M.T., Decensi, A. (2004). Factors associated with circulating levels of insulin-like growth factor-I and insulin-like growth factor binding protein-3 in 740 women at risk for breast cancer. Breast Cancer Res. Treat., 88(1), 63-73.
Kaczka, A., Kumor, A., Pietruczuk, M., Małecka-Panas, E. (2007). Serum concentration of insulin, C-peptide and insulin-like growth factor I in patients with colon adenomas and colorectal cancer. Pol. Merkur Lekarski, 22(131), 373-375 (in Polish)

Morimoto, L.M., Newcomb1, P.A., White, E., Bigler, J., Potter, J.D. (2005). Insulin-like growth factor polymorphisms and colorectal cancer risk. Cancer Epidemiol. Biomarkers Prevent., 14, 1204-1211.

Duffy, M.J. (2001). Carcinoembryonic Antigen as a Marker for Colorectal Cancer: Is it clinically useful? Clinical Chemistry, 47, 624-630.

Renehan, A.G., Zwahlen, M., Minder, C., O'Dwyer, S.T., Shalet, S.M., Egger, M. (2004). Insulin-like growth factor (IGF)-I, IGF binding protein-3, and cancer risk: Systematic review and meta-regression analysis. Lancet, 363(9418), 1346-1353.

Schiemann, U., Günther, S., Gross, M., Henke, G., Müller-Koch, Y., König, A., Muders, M., Folwaczny, C., Mussack, T., Holinski-Feder, E. (2005). Preoperative serum levels of the carcinoembryonic antigen in hereditary non-polyposis colorectal cancer compared to levels in sporadic colorectal cancer. Cancer Detect. Prev., 29(4), 356-360.

Tan, E., Gouvas, N., Nicholls, R.J., Ziprin, P., Xynos, E., Tekkis, P.P. (2009). Diagnostic precision of carcinoembryonic antigen in the detection of recurrence of colorectal cancer. Methods Mol. Biol., 472, 307-321.

Tripkovic, I., Tripkovic, A., Strnad, M., Capkun, V., Zekan, L. (2007). Role of insulin-like growth factor-1 in colon cancerogenesis: A case-control study. Arch. Med. Res., 38(5), 519-525.

Received 11 July 2009

\section{INSULĪNAM LİDZĪGĀ AUGŠANAS FAKTORA I (IGF-I) UN KONVENCIONĀLO BIOMARKIERU SALĪDZINOŠA ANALİZE PACIENTIEM AR AUDZĒJIEM DIAGNOZES NOTEIKŠANAS BRĪDI}

Atsevišḳos pētījumos pacientiem ar laundabīgiem audzējiem ir konstatēta paaugstināta insulīnam līdzīgā augšanas faktora I koncentrācija. Dažos pētījumos insulīnam līdzīgais augšanas faktors I ir pierādīts kā riska biomarkiieris kolorektālā un krūts vēža gadījumā. Mēs savā pētījumā noteicām IGF-1, CA19-9, CEA un CA72-4 kolorektālā, CA15-3 un CEA krūts vēža gadījumā ar mērki noskaidrot IGF-I lietderību audzēju diagnostikā. Tika izanalizētas 42 sievietes un 52 vīrieši ar kolorektālo vēzi un 139 sievietes ar krūts vēzi. Vidējā IGF-I koncentrācija tika aprēkināta, kontroles grupā iekḷaujot uz izmeklējuma brīdi veselus 27 vīriešus un 130 sievietes. IGF-I un ar audzēju saistîtie biomarkieri tika noteikti ar hemiluminiscences metodi, izmantojot Immulite 2000 analizatoru. Paaugstināts IGF-1 līmenis tika konstatēts $42,8 \%$ vīriešiem un 30,7 \% sievietēm ar kolorektālo vēzi. Izmantojot divu biomarkieru kombināciju, kolorektālo vēžu diagnostikas rādītāji bija augstāki gan vīriešiem, gan sievietēm $(57,1 \%$ un 57,6\%). Starp krūts vēža pacientēm augstāka IGF-1 diagnostiskā vērtība bija sievietēm menopauzē salīdzinājumā ar sievietēm premenopauzē (33,6\% pret 27,7\%). Insulīnam līdzīgais augšanas faktors I var tikt izmantots kā papildus biomarḳieris kolorektālā un krūts vēža diagnostikā atsevišķām pacientu grupām. 